


\title{
SIJASYNKRETISMI MORFOLOGIAN KOETINKIVENÄ
}

\author{
Riho Grünthal \\ Helsingin yliopisto
}

Kokkuvõte. Käändesünkretism morfoloogia proovikivina.

Käesolevas artiklis vaadeldakse sünkretismi ehk vormihomonüümiat läänemeresoome keelte käändesüsteemis. Erilist tähelepanu pälvivad lõunarühma keeled, kus kahe käändevormi identsuses väljenduv sünkretism on sagedasem kui põhjarühma keeltes. Kahe vormi vaheline identsus võib teatud juhtudel täielikult kaotada kahe kategooria vahelise erinevuse. Sellisel juhul ei pruugi sünkretism erineda üksikvormide mitmetähenduslikkusest.

Kuigi sünkretism tuleneb sageli keele diakroonilistest muutustest ja keeleajaloo vahendite abil tuvastatavatest protsessidest, võib sünkretismi vaadelda ka sünkroonilise nähtusena. Sellisena tähendab sünkretism eelkõige kahe kategooria vahelise piiri kadumist. Paradigmaatilisest seisukohast on põhiküsimuseks eelkõige see, milliseid kategooriaid sünkretism puudutab, kas sõnatüüpide erinevused avalduvad ka sünkretismis ning milliseid reegleid on võimalik leida. Diakrooniliselt võib sünkretismi vaadelda ühest küljest nähtuse tekkeloo seisukohast, teisest küljest kausaalse ilminguna, mis on seotud ka teiste muutustega.

Kuigi läänemeresoome keeled on omavahel lähedased sugulaskeeled, valgustab sünkretism nende morfoloogias ja keelte iseärasustes peituvaid erinevusi. Samad käändevormid, mis alluvad flekteerivale morfoloogiale, on mõjutatud ka sünkretismist. Ometi pole sünkretismi paradigmaatiline esinemine ega kategooriate kokkulangemine eri keeltes identsed. Artiklis vaadeldakse lähemalt mh soome, võru ja liivi keele näitel sünkreetiliste vormide sümmeetriat ja asümmeetriat.

Märksõnad: morfoloogia, sünkretism, tüpoloogia, läänemeresoome keeled, lõunaeesti, liivi 
Morfeemeja eli pienimpiä merkitystä kannattavia yksiköitä voidaan luonnehtia kielen perimäksi (Kangasmaa-Minn 1992). Taivutuspäätteet ja niiden varaan rakentuva suffiksaalinen morfologia ovat runsaasti morfologisia muotoja ja kategorioita sisältävässä kielessä mikroskooppisia tiedonjyviä, joihin on tiivistetty tieto kieliopillisesta merkityksestä, sanojen taivutuksesta ja niiden käyttöä säätelevistä säännöistä. Kielen ymmärtämisen ja puhetilanteen etenemisen kannalta morfeemit joustavat vähiten. Sääntöihin mahtuu poikkeuksia ja poikkeuksien poikkeuksia, mutta niillä on rajansa. Rajallinen määrä morfeemeja voi silti sisältää lähes rajattoman määrän mahdollisuuksia yhdistellä muotoja ja merkityksiä käsitteiksi, konstruktioiksi ja lausekokonaisuuksiksi.

\section{Yksi muoto, monta merkitystä}

Tämän artikkelin lähtökohtana on synkretismi eli taivutushomonymia, muodon ja merkityksen välisen tasapainon horjuminen itämerensuomalaisissa kielissä. Vaikka ihanteellinen tilanne, jossa yhtä muotoa vastaa yksi merkitys, toteutuu vain harvoin, synkretismi poikkeaa joiltakin osin tavallisesta monimerkityksisyydestä ja polysemiasta. Se on useimmin yhdistetty leksikaaliseen monimerkityksisyyteen, mutta sitä voidaan tarkastella myös kieliopin kannalta. Polysemian lähtökohta on merkityksen laajeneminen, laajemman konstruktion tai lauseeseen kuuluvien konstituenttien aiheuttama tulkinta, joka eri kontekstissa saa erilaisia merkityksiä (Croft 2000: 259, Hopper ja Traugott 1993: 100, Leino 1993, Leino ja Onikki 1994).

Myös synkretismi liittyy merkityksen laajenemiseen, mutta sen olemassaolo ei perustu morfeemin lausesemanttiseen tulkintaan, vaan morfologiseen rakenteeseen. Tavallisesti kyse on kielessä tapahtuneesta diakronisesta muutoksesta. Synkretismissä on siten kyse kahden morfeemin välisen eron ja distinktiivisten muotokategorioiden välisen rajan hämärtymisestä tai täydellisestä katoamisesta. Tällaisena synkretismi ilmenee synkronisella tasolla, mutta sen taustalla on diakroninen muutos (Baerman ym. 2005: 38, Luraghi 2008). Toisaalta synkretismin 
piiriin luetaan kuuluvaksi myös sellainen morfologisten muotojen samankaltaisuus ja monimerkityksisyys, joka ei aina johdu diakronisesta muutoksesta ja saattaa koskea vain yksittäisiä taivutustyyppejä. Esimerkiksi Meiser (1992) erottaa toisistaan kaksi erilaista synkretismiä, paradigmaattisen ja diakronisen. Morfologian tutkimuksessa synkretismiä tarkastellaankin tavallisesti paradigmaattisena ilmiönä: taivutusmuotoina, joilla on useita morfosyntaktisia merkityksiä ottamatta kantaa niiden syntyhistoriaan (Aronoff ja Fudemann 2005: 169-170, Bauer 1988: 255, Bickel ja Nichols 2007, Carstairs 1987, Malchukov ja Spencer 2009, Stump 2001: 212-241).

Paradigmaattisesti tarkasteltuna olennaisinta synkretismissä on, mitä kategorioita se koskee ja kuinka systemaattista se on. Diakroniselta kannalta sen sijaan synkretismi liittyy kiinteästi kielen muutosmekanismeihin, joka voi raottaa myös kausaalista kysymystä, miten eri muutokset liittyvät toisiinsa. Kahden morfologisen kategorian identtisyys voi neutralisoitua synkretistisiä muotoja sisältävässä lauseessa, mutta usein tällaisissa lauseissa voidaan tarkkailla sitä, kuinka kieli reagoi morfologisten kategorioiden välisen eron hämärtymiseen. Kieli paljastaa tällaisessa tapauksessa sisäisen evoluutiomekanisminsa, joka joutuu sopeutumaan siihen, miten muoto ja merkitys, nuo kieliopin dna-järjestelmän kromosomiparit, pidetään järjestyksessä.

Tarkastelen seuraavassa synkretismin vaikutusta itämerensuomalaisten kielten morfologiaan ja laajemmin kieliopilliseen järjestelmään, ja erityisesti sen merkitystä sijataivutukseen. Ilmiön havainnointi on lähtenyt usein nimenomaan (indoeurooppalaisten kielten) sijataivutuksesta (Baerman ym. 2005: 38, Carstairs 1987, Joseph 1990, Luraghi 2008), mutta sitä voidaan seurata yhtä lailla verbitaivutuksenkin alueella. Synkretistisinä voitaisiin historiallisen kehityksen takia pitää myös joitakin ikivanhoja, koko kielialuetta yhdistäviä tapauksia, jotka eivät synkronisessa kieliopin tarkastelussa näytä enää kaksilähtöisiltä, vaan pikemminkin yhdestä muotokategoriasta lähtöisin olevalta polysemialta. Tunnetuin esimerkki tästä itämerensuomalaisissa kielissä on genetiivin käyttö sekä omistajaa että objektia ilmaisemassa sen lisäksi, että genetiivin avulla muodostetaan myös attribuutti- ja postpositiolausekkeita. Tällaiset genetiivin ja akku- 
satiivin yhteen sulautumisen kaltaiset, itämerensuomalaisten kielten varhaishistoriaan kuuluvat kysymykset jäävät kuitenkin tämän artikkelin ulkopuolelle. Huomioni pääkohteena on se, mitä kategorioita synkretismi koskee eri itämerensuomalaisissa kielissä ja miten se vaikuttaa kieleen järjestelmänä.

Synkretismin tarkastelua itämerensuomalaisissa kielissä motivoi osaltaan se, että vaikka kielet ovat toistensa lähisukukieliä, useat keskeiset erot paljastuvat juuri morfologiassa. Kielitypologian eri suuntauksia ja maailman kielten vertautuvuutta arvioitaessa on väitetty, että kaikista kielen rakenteellisista osa-alueista nimenomaan morfologia on kielikohtaisin ja vaikein asettaa yleispätevään kehykseen (Baerman ja Corbett 2007: 115, Haspelmath 2007). Väite pätee esimerkiksi tämän artikkelin valossa hyvin myös niinkin läheisiin kielivariantteihin kuin itämerensuomalaisiin kieliin. Morfologiset erot näkyvät eri tavoin, joista suffiksaalisen (agglutinatiivisen) morfologian korvautuminen sanavartalon vaihtelulla (flekteeravalla morfologialla) eli kulloinkin kyseessä olevaa taivutuskategoriaa koskeva taivutustypologinen muutos on yksi dramaattisimpia. Toinen morfologista järjestelmää muuttava tekijä joka heikentää taivutusparadigmoissa ilmenevää kielen tapaa jäsentää merkitystehtäviä muodon perusteella, on synkretismi.

Virolaisessa ja suomalaisessa kielioppitraditiossa synkretismi on jäänyt varsin vähälle huomiolle, vaikka taivutusmorfologian rajat tulevat konkreettisimmin vastaan juuri sellaisissa tapauksissa, jossa kahden muodon välinen ero katoaa. Esimerkiksi Iso suomen kielioppi (ISK) ei mainitse synkretismiä ollenkaan, eikä ilmiö olekaan erityisen tärkeä suomen kieliopin kannalta (ks. kuitenkin alempana possessiivitaivutus ja taulukko 1.). Viron kieliopin kuvauksessa synkretismi tunnetaan periaatteessa (Viks 1984, Erelt ym. 1997: 523-529, Grünthal 2001), mutta sen yleisyyteen verrattuna se sivuutetaan yllättäen usein vähin sanoin tai jätetään jopa kokonaan huomiotta (esim. Erelt ym. 1993-1995).

\section{Eri näkökulmia synkretismiin}

Paradigmaattista synkretismiä on morfologian teoriassa käsitelty lähinnä kahdesta näkökulmasta. Toisaalta on yritetty selvittää, 
minkä kategorioiden välillä synkretismiä tavallisesti esiintyy niin, että ne voivat sen välityksellä yhdistyä toisiinsa, ja kuinka järjestelmällistä se on (Baerman ym. 2005). Toisaalta on tarkasteltu, mitä eroja monifunktioisten, morfosyntaktisesti kumulatiivisten ja yksinkertaisempien kategorioiden välillä on. Surreyn yliopiston morfologian tutkimusryhmän synkretismitietokantaan on koottu tietoa maailman kielissä esiintyvistä synkretismikombinaatioista, joista käy ilmi, että myöskään synkretismin esiintymistä eivät ohjaa mitkään absoluuttiset universaalit, jotka pätevät aukottomasti kaikkiin maailman kieliin (ks. SD). Suoremmin synkretismin esiintyminen näyttää riippuvan siitä, esiintyykö kielessä suffikseja vai ei. Synkretismi on selvästi yleisempi ilmiö sellaisissa kielissä, joissa esiintyy taivutus- ja sijapäätteitä, kuin niissä, joissa suffikseja ja sijoja ei ole ollenkaan tai niitä on vain hyvin vähän.

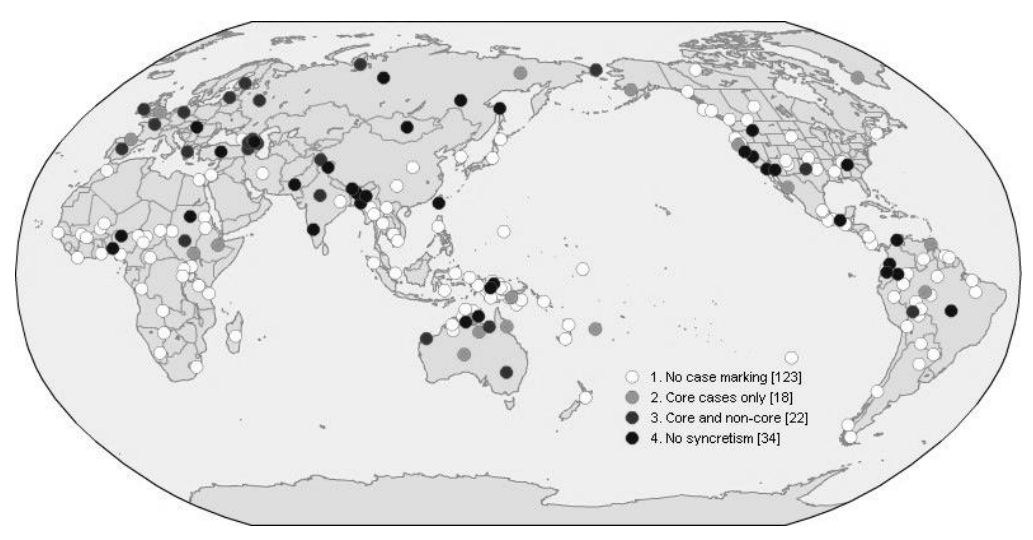

Kartta 1. Sijasynkretismi maailman kielissä (Baerman ja Brown 2005). Otoksen 197 kielestä 157:ssä ei esiinny ollenkaan synkretismiä, 40:ssä esiintyy.

Universaalit yleistykset eivät kuitenkaan kerro kielikohtaisista rajoituksista ja ilmiön esiintymistä säätelevistä tapauskohtaisista morfologisista säännöistä. Tähänastisen tutkimuksen valossa on vaikea osoittaa yleispäteviä sääntöjä, sillä kussakin tapauksessa kielen oma morfologia sanelee ehdot. Synkretististen tapausten ääripään muodostavat taivutusparadigmat, joissa 
yhdellä taivutusmuodolla voidaan ilmaista useita merkityksiä samanaikaisesti. Useissa uralilaisissa kielissä (mordvalais-, ugrilais- ja samojedikielet) esiintyvä objektikonjugaatio valaisee hyvin muodon ja merkityksen välistä kompleksisuutta, koska yhdellä muodolla voidaan ilmaista ääritapauksessa sekä subjektin että objektin persoonaa ja lukua. Tämä sääntö ei kuitenkaan ole täysin pitävä, koska eri kielten objektikonjugaatioparadigmojen välillä on isoja eroja, ja paradigman rakenne riippuu sekä subjektin että objektin persoonasta.

Synkretismin esiintyminen kaiken kaikkiaan on varsin huonosti ennustettavissa, koska kielen jatkuva muutostila ja sananloppuisten ainesten taipumus kulua tai kokonaan kadota voivat periaatteessa koskea mitä tahansa kielen osa-aluetta ja taivutuskategoriaa. Morfologian tutkimuksessa esitetyn teesin mukaan synkretismi tai monifunktionaalisuus on tavallisempaa morfologisesti kompleksisissa kategorioissa kuin silloin, kun suffiksilla on morfosyntaktisesti rajattu tehtävä (Carstairs 1987).

Tämäkään sääntö ei ole täysin aukoton, koska sille on helppo esittää vastaesimerkkejä. Esimerkiksi mordvalaiskielten objektikonjugaation taivutusparadigma on täydellinen, jos objektina on yksikön kolmas persoona. Muissa tapauksissa paradigmassa esiintyy huomattavan paljon synkretismiä, ja oletus, että paradigma olisi historiallisesti ollut joskus täydellinen (Bátori 1990) on virheellinen (Keresztes 1999). Obinugrilaisten ja samojedikielten objektikonjugaatiossa taas objektin persoonaa ei eroteta, ainoastaan luku, mikä periaatteessa lisää synkretismiä.

Tällaisessa ääritapauksessa synkretismi ei kuitenkaan ole välttämättä oikea käsite kuvaamaan ilmiötä ollenkaan, koska kyse on pikemmin yksittäisten muotojen polysemiasta, ei diakronisesta kehityksestä aiheutuvasta yhteen sulautumisesta, mitä synkretismillä tavallisesti tarkoitetaan.

Synkretismiä on toisinaan kutsuttu taivutushomonymiaksi, ja sen on katsottu jakautuvan systemaattiseen (systematic inflectional homonymy) ja satunnaiseen (accidental/random inflectional homonymy) homonymiaan (Carstairs 1987, Johnston 1997). Myös viron kielen tutkimuksessa on ollut käytössä leksikaalisten muotojen samankaltaisuuteen viittaava homonymian käsite (Erelt ym. 1997: 523-529, Grünthal 2002). Käsitteelliseen eroon 
sisältyy tärkeä teoreettinen ero. Taivutushomonymia viittaa taivutettujen sanamuotojen väliseen identtisyyteen, kun taas synkretismi lähtee enemmän siitä ajatuksesta, että kyseessä on kahden kategorian välinen sulautuminen yhdeksi. Nämä kaksi näkökulmaa ovatkin tärkeitä tarkasteltaessa itämerensuomalaisten kielten synkretismiä, sillä kumpaakin tyyppiä esiintyy.

Stump (2001: 212-241) tarkastelee synkretismiä ja sen vaikutusta paradigmoihin formaalin kielentutkimuksen ja autonomisen morfologian näkökulmasta. Hän erottaa neljä erityyppisiä hierarkkisia suhteita ilmentävää synkretiatapausta, joista hän käyttää käsitteitä unidirectional, bidirectional, unstipulated ja symmetrical. Hänen lähtökohtanaan on se, että erityyppiset synkretismit ilmentävät hierarkkisia suhteita ja synkretismin tyyppi riippuu siitä, kuinka sen piiriin kuuluvat kategoriat ja taivutusmuodot vaikuttavat toisiinsa.

Synkretismiä näyttää olevan tarkoituksenmukaista tarkastella sen kannalta, kuinka ehdotonta kahden tai useamman taivutuskategorian välinen identtisyys on, vai vaikuttavatko siinä muut säännöt, kuten taivutustyyppien välillä vallitsevat erot synkretismiin. Kyse on siis siitä, että esimerkiksi virossa sijasynkretismin esiintyminen riippuu taivutustyypistä ja on siten alisteinen leksikaalisesti johdettaville morfologisille säännöille (Blevins 2005, Grünthal 2001, Viks 1984). Sama pätee liiviin (vrt. Viitso 2008: 348-355), jossa tavataan useita erilaisia kombinaatioita.

Tällä perusteella voidaan erottaa toisistaan kaksi erilaista synkretismin lajia, joista käytän seuraavassa nimityksiä symmetrinen ja asymmetrinen synkretismi, edellistä eri merkityksessä kuin Stump. Symmetrisellä synkretismillä tarkoitan paradigmaattisesti ennustettavaa, esimerkiksi kahden sijan järjestelmällistä sulautumista yhteen siten, että mitkään muut tekijät eivät vaikuta siihen. Asymmetrisellä synkretismillä tarkoitan taas sitä, että jonkin muun morfologisen säännön takia paradigmassa onkin kohtia, joihin synkretismi ei vaikuta. Tällöin synkretistiset muodot jakaantuvat epätasaisesti taivutusparadigmassa ja myös synkretismin alaiset kategoriat voivat vaihdella, koska eri taivutustyyppiin kuuluvien sanojen välillä on eroja. Niihin vaikuttavista säännöistä tulee alempana lähemmin puhetta. 


\section{Symmetrinen synkretismi}

Itämerensuomalaisista kielistä synkretismi vaikuttaa kaikista vähiten suomen kielen morfologiaan, jos lähtökohtana pidetään yleiskieltä. Murteissa tilanne on toisinaan toinen (Paunonen 2003), mutta jätän ne tämän tarkastelun ulkopuolelle. Suomen yleiskielessä synkretismi rajoittuu polysemiaa muistuttaviin yksittäistapauksiin, kuten nominatiivissa oleviin possessiivisuffiksillissiin muotoihin lapse-ni, lapse-si, lapse-nsa, lapse-mme, lapse-nne, lapse-nsa. Nominatiivissa ei tehdä minkäänlaista eroa siinä, onko omistettuja yksi vai monta, ja lisäksi kolmannessa persoonassa ei eroteta omistajan lukua (yksikköä ja monikkoa). Muissa sijoissa omistetun luku erotetaan lisäämällä monikon tunnus samalla tavalla kuin suomalais-ugrilaisissa kielissä on yleensä tapana tehdä, ja ainoastaan kolmannen persoonan luku jää erottamatta: las-ta-ni : lapsi-a-si; las-ta-mme : lapsi-a-mme. Agglutinatiivinen taivutusmorfologia ja suffiksien liittäminen toisiinsa toimivat, vaikka joissakin sanatyypeissä, kuten tässä esimerkkinä olevassa, runsas allomorfismi hämärtää sitä. Suffiksien erottamiseen perustuva morfologia on kuitenkin niin johdonmukainen, että myös nuorimmat vierasperäiset sanat mukautuvat sellaisiin taivutustyyppeihin, joissa tehdään johdonmukainen ero vartalomorfeemin, monikon tunnuksen ja sijapäätteen välillä, kuten sanoissa bändi $:$ bändi-t $:$ bände-j-ä : bände-i-hin; bitti : biti-t $:$ bitte-j- $\ddot{a}:$ bite-i-ssä; jengi $:$ jengi- $t$ : jenge-j-ä $:$ jenge-i-ssä jne. Myös uudemmalle Helsingin slangille on ominaista runsas analogisten mallimuodosteiden käyttäminen (Paunonen 2006).

Suomen yleiskielen kannalta täysin symmetrinen ja taivutusparadigmassa säännöllinen synkretismi on marginaalinen ilmiö eikä olennainen kieliopin kuvauksen kannalta. Vaikka edellä mainitut possessiivisuffiksilliset nominatiivimuodot poikkeavat muista sijoista, synkretismi on systemaattista kaikissa persoonissa. 


\begin{tabular}{|l|l|l|l|l|l|l|}
\hline SIJA & SG1 & SG2 & SG3 & PL1 & PL2 & PL3 \\
\hline NOM & talo-ni & talo-si & talo-nsa & talo-mme & talo-nne & talo-nsa \\
\hline GEN.SG & talo-ni & talo-si & talo-nsa & talo-mme & talo-nne & talo-nsa \\
\hline GEN.PL & talo-je-ni & talo-je-si & talo-je-nsa & talo-je-mme & talo-je-nne & talo-je-nsa \\
\hline PART & $\begin{array}{l}\text { talo-a-ni } \\
\text { talo-j-a-ni }\end{array}$ & $\begin{array}{l}\text { talo-a-si } \\
\text { talo-j-a-si }\end{array}$ & $\begin{array}{l}\text { talo-a-nsa } \\
\text { talo-j-a-nsa }\end{array}$ & $\begin{array}{l}\text { talo-a-mme } \\
\text { talo-j-a-mme }\end{array}$ & $\begin{array}{l}\text { talo-a-nne } \\
\text { talo-j-a-nne }\end{array}$ & $\begin{array}{l}\text { talo-a-nsa } \\
\text { talo-j-a-nsa }\end{array}$ \\
\hline ILL & $\begin{array}{l}\text { talo-o-ni } \\
\text { talo-i-hi-ni }\end{array}$ & $\begin{array}{l}\text { talo-o-si } \\
\text { talo-i-hi-si }\end{array}$ & $\begin{array}{l}\text { talo-o-nsa } \\
\text { talo-i-hi-nsa }\end{array}$ & $\begin{array}{l}\text { talo-o-mme } \\
\text { talo-i-hi-mme }\end{array}$ & $\begin{array}{l}\text { talo-o-nne } \\
\text { talo-i-hi-nne }\end{array}$ & $\begin{array}{l}\text { talo-o-nsa } \\
\text { talo-i-hi-nsa }\end{array}$ \\
\hline INE & $\begin{array}{l}\text { talo-ssa-ni } \\
\text { talo-i-ssa-ni }\end{array}$ & $\begin{array}{l}\text { talo-ssa-si } \\
\text { talo-i-ssa-si }\end{array}$ & $\begin{array}{l}\text { talo-ssa-nsa } \\
\text { talo-i-ssa-nsa }\end{array}$ & $\begin{array}{l}\text { talo-ssa-mme } \\
\text { talo-i-ssa-mme }\end{array}$ & $\begin{array}{l}\text { talo-ssa-nne } \\
\text { talo-i-ssa-nne }\end{array}$ & $\begin{array}{l}\text { talo-ssa-nsa } \\
\text { talo-i-ssa-nsa }\end{array}$ \\
\hline ELA & $\begin{array}{l}\text { talo-sta-ni } \\
\text { talo-i-sta-ni }\end{array}$ & $\begin{array}{l}\text { talo-sta-si } \\
\text { talo-i-sta-si }\end{array}$ & $\begin{array}{l}\text { talo-sta-nsa } \\
\text { talo-i-sta-nsa }\end{array}$ & $\begin{array}{l}\text { talo-sta-mme } \\
\text { talo-i-sta-mme }\end{array}$ & $\begin{array}{l}\text { talo-sta-nne } \\
\text { talo-i-sta-nne }\end{array}$ & $\begin{array}{l}\text { talo-sta-nsa } \\
\text { talo-i-sta-nsa }\end{array}$ \\
\hline
\end{tabular}

Taulukko 1. Sija- ja persoonasynkretismi suomen kielen omistustaivutuksessa.

Paradigmaattisesti tarkasteltuna suomen possessiivitaivutuksessa ilmenevä synkretismi ei ole täysin merkityksetön, koska se koskee nominatiivissa omistetun määrän lisäksi sijakategoriaa. Jos omistettuja on yksi, possessiivisen taivutuksen nominatiivi ja genetiivi ovat identtisiä. Muuten suomen possessiivitaituvus noudattaa uralilaisissa kielissä tavallisesti tavallista sääntöä, jonka mukaan persoonapäätteen avulla tehdään ero omistajan persoonan ja luvun välillä. Sen sijaan omistetun lukua ilmaistaan yksinkertaisesti numerustunnuksen eli kaksikon tai monikon tunnuksen avulla. Taulukossa 1 esitetyn synkretismin ehtona ovat seuraavat kolme sääntöä, jotka kaikki koskevat eri osaalueita:

(i) Sijasynkretismi: Jos omistettuja on yksi, ei nominatiivin (NOM) ja genetiivin (GEN) välillä tehdä eroa.

(ii) Lukusynkretismi: Jos kyseessä on nominatiivi, ei omistetun lukua eli yksikköä (SG) ja monikkoa (PL) eroteta.

(iii) Persoonasynkretismi: Jos omistaja on kolmannessa persoonassa, ei yksikköä (3SG) ja monikkoa (3PL) eroteta toisistaan. 
Suomen possessiivitaivutuksen synkretistisille muodoille on ominaista se, että ne ovat kategoriakohtaisesti ennustettavissa ja yleistettävissä. Toisin on esimerkiksi virossa, jossa synkretismin levinneisyys taivutusparadigmassa vaihtelee paljon eri taivutustyypeistä riippuen. Kategoriakohtaisesti ennustettava synkretismi korreloi itämerensuomalaisissa kielissä myös morfologisen typologian kanssa. Jos kyseessä oleva kategoria erotetaan suffiksien avulla, synkretismi koskee koko kategoriaa. Jos sen sijaan taivutusmuotojen erottaminen perustuu fleksiomuotoihin ja leksikaaliset säännöt säätelevät niitä, morfologiset muodot eivät ole kategorian perusteella ennustettavia ja synkretismi on epäsymmetristä, mistä tulee alla lähemmin puhetta. Synkretismi toimii siten tärkeänä morfologisen rakenteen ja taivutustypologian arviointikriteerinä. Suomen possessiivitaivutuksessa ilmenevän synkretismin tarkastelu osoittaa selvästi sen, mihin asti sanavartalon vaikutusalue ulottuu. Morfeemit ovat selvärajaisia eivätkä sanavartalossa tapahtuvat muutokset vaikuta millään tavalla synkretismiin.

Samanlaista symmetristä, kategoriakohtaisesti ennustettavaa synkretismiä esiintyy myös muissa itämerensuomalaisissa kielissä. Kattavaa kategorioiden välistä eri muotojen yhteen sulautumista ei usein edes käsitellä synkretisminä, koska synkronisesti tarkasteltuna se ilmenee polysemian tavoin. Karjalassa allatiivi ja adessiivi ovat sulautuneet yhdeksi tulo- ja olosijan funktioita täyttäväksi kategoriaksi (Kettunen 1960: 17). Historiallinen kaksilähtöisyys näkyy vain vertaamalla karjalaa sen sukukieliin, mutta synkronisen kieliopin kannalta kyseessä on yksi sija. Vepsän kolmannessa paikallissijasarjassa, approksimatiivisissa, jonkin luo tulemista tai luona olemista ilmaisevissa $n$-sijoissa tuloja olosija ovat pysyneet erillään etelävepsässä (Tikka 1992: 47, 121-143) ja keskivepsän itäisimmässä osassa, kun taas pohjoisja keskivepsän läntisellä alueella ne ovat sulautuneet yhdeksi sijaksi: hebo-nno 'hevosen luo; hevosen luona'.

Joskus oletus synkretismistä voi osoittautua paikkaansa pitämättömäksi. Muiden itämerensuomalaisten kielten translatiivia vastaava liivin $-k s$-sijaa pidettiin pitkään kaksilähtöisenä translatiivi-komitatiivina (Kettunen 1938: XLII-XLIII, Laanest 1982: 167, 173). Suffiksin monifunktionaalisuus on tässä tapauksessa 
kuitenkin merkityksen laajenemisen tulosta eli funktionaalista polysemiaa (Grünthal 2003: 177-202). Esimerkiksi Tiit-Rein Viitso (2008: 348-355) kutsuu sijaa latvian kielioppia vastaavalla tavalla instrumentaaliksi. Suomeksi tai viroksi käännettynä liivin instrumentaali saa kaksi erilaista vastinetta: liestāks kampela-INST 'kampelaksi; kampelan kanssa', rikkõks rikas-INST 'rikkaaksi; rikkaan kanssa', naizõks nainen-INST 'naiseksi; naisen kanssa'.

Synkretismin tunnistaminen on helpompaa sellaisissa tapauksissa, joissa se toteutuu vain tietyin ehdoin. Liivin nominatiivin ja genetiivin välisen eron katoaminen on vaikuttanut voimakkaasti kieliopillisten sijojen järjestelmään ja nominaalisten lauseenjäsenten väliseen hierarkiaan. Monikossa nominatiivi ja genetiivi ovat täysin identtisiä ja nominatiivia käytetään myös genetiivin asemassa. Kyseessä ei synkronisesti ajateltuna tarkalleen ottaen ole edes synkretismi, vaan nominatiivin semanttisen roolin laajeneminen, siis polysemia, vaikka historiallisesti monikon nominatiivi ja genetiivi ovat eri sijoja liivissäkin. Synkretismitulkintaa tukee kuitenkin myös se, että yksikössä nominatiivin ja genetiivin sulautuminen yhteen toteutuu vain osassa nomineista.

Tässä tapauksessa siirrytään selvästi toisentyyppisen, asymmetrisen synkretismin alueelle, joka ei ole kategoriakohtaisesti ennustettavissa. Onkin esitetty, että asymmetriset rakenteet ovat periaatteessa kompleksisempia, kielen järjestelmää kuormittavampia kuin symmetriset (Miestamo 2006: 353).

\section{Asymmetrinen synkretismi}

Itämerensuomalaisten kielten eteläryhmän kielille on ominaista kieliopillisten sijojen morfologisten erojen muutos ja fleksiomorfologian merkitys taivutusjärjestelmälle. Erityisesti genetiivin $n$-päätteen kato, mutta osin myös partitiivissa tapahtuneet muutokset ovat vaikuttaneet kieliopillisten sijojen väliseen suhteeseen. Tämä on luonteenomaista etenkin virolle, etelävirolle (võru) ja liiville. Pienemmässä määrin se koskettaa myös suomen lounaismurteita ja vatjaa (Grünthal 2007: 414-419, Pauno- 
nen 2003: 220). Kaikissa näissä tapauksissa synkretismi ja tiettyjä taivutustyyppejä koskevat säännöt hämärtävät entisestään paradigmaa. Yhteistä kaikille tapauksille on, että leksikaaliset säännöt vaikuttavat paradigman rakenteeseen. Kategoriakohtaisen ennustettavuuden lisäksi on siis toinen ehto, kulloinkin vallitseva taivutustyyppi, jonka toteutuminen säätelee synkretismin esiintymistä.

\begin{tabular}{|c|c|c|c|c|c|c|}
\hline & $\begin{array}{l}\text { 'kylä' } \\
\text { SG }\end{array}$ & $\begin{array}{l}\text { 'kylä' } \\
\text { PL }\end{array}$ & $\begin{array}{l}\text { 'leppä' } \\
\text { SG }\end{array}$ & $\begin{array}{l}\text { 'leppä' } \\
\text { PL }\end{array}$ & $\begin{array}{l}\text { 'permanto' } \\
\text { SG }\end{array}$ & $\begin{array}{l}\text { 'permanto' } \\
\text { PL }\end{array}$ \\
\hline NOM & külä & külä-q & lepp & lepä-q & põrmand & põrmandu- $q$ \\
\hline GEN & külä & kül'li & lepä & leppi & põrmandu & põrmand-iidõ \\
\hline PART & küllä & kül'li & leppä & leppi & põrmandu- $t$ & põrmand-iid \\
\hline ILL & `küllä & 'kül'li & leppä & leppi & põrmandu-he & põrmand-ihe \\
\hline INE & külä-h & küli-h & lepä-h & lepi-h & põrmandu- $h$ & põrmand-ih \\
\hline
\end{tabular}

Taulukko 2. Synkretismi võrun sijataivutuksessa (Keem 1997: 24-34).

Hella Keemin esittämistä võrun kielen taivutusparadigmoista poimitut esimerkit valaisevat asymmetrisen synkretismin olemusta. Sijasynkretismin esiintyminen riippuu taivutustyypistä, ja taivutustyyppiin vaikuttavat sanan tavumäärä ja allomorfismin ja morfofonologisen vaihtelun säätelemät säännöt. Taulukon 3 esimerkeistä käy ilmi, että synkretismin vaikutusalue ja toteutuminen riippuvat näissä tapauksissa seuraavista ehdoista: (i) onko sana yksi-, kaksi- vai useampitavuinen, (ii) kaksitavuisten sanojen vartalovokaalista, (iii) astevaihtelun aiheuttamasta morfofonologisesta vaihtelusta, (iv) kestoasteesta ja (v) monikollisissa muodoissa siitä, käytetäänkö kyseessä olevassa sanatyypissä - $i$ vai -di-monikkoa.

Edellisten lisäksi taulukkoon liittyy yksi säännönmukaisuus, joka kertoo itse asiassa myös alkuperäisen lähteen eli Keemin (1997) noudattamasta konventiosta. Keemin erikseen paradigmassa esittämät inessiivi ja essiivi ovat säännöllisesti identtisiä 
sekä yksikössä että monikossa. Essiivi ei tämän perusteella itse asiassa esiinny itsenäisenä kategoriana, vaikka funktionaalisen eron perusteella asymmetriseen paradigmaan limittyy näennäisesti symmetrisen synkretismin aineksia. Perustellummin voitaisiin puhua inessiivin polysemiasta ja vähentää sijaparadigmaan kuuluvien sijojen määrää yhdellä. Symmetria ei kuitenkaan ole aivan aukoton, ja Keem (mts. 31) esittääkin yhden sanatyypin, jossa monikon inessiivin ja essiivin välillä tehdään ero: puи : puu- $q$ puu-PL : $p u-i \tilde{o} h$ puu-PL-INE : $p u-i h$ puu-PL-ESS.

Sulev Ivan (2007: 75-78, 147-201) võrun kirjakieleen perustuvassa luokittelussa synkretismi ei ole yhtä hallitseva kuin Keemiltä lainaamassani taivutustyypeissä. Iva jakaa nominit yhteensä 47 taivutustyyppiin, joissa esiintyy neljänlaista sijasynkretismiä: yksikössä nominatiivi-genetiivi ja partitiivi-illatiivi, monikossa genetiivi-partitiivi ja genetiivi-partitiivi-illatiivi. Viimeisessä tapauksessa synkretismin levikkiä voi vähentää se, että lyhyen illatiivin rinnalla esiintyy analoginen -he-illatiivi, joka Ivan mukaan voi esiintyä kaikissa niissä tapauksissa, joita yhteen sulautuminen genetiivin ja partitiivin kanssa koskisi.

Taulukossa 3 on esitetty synkretististen tapausten määrä võrun nominitaivutuksessa Ivan mukaan. Luvut koskevat eri taivutustyypeissä esiintyviä synkretiatapauksia, eivät niiden esiintymätiheyttä võrunkielisessä tekstissä.

\begin{tabular}{|c|c|c|c|c|c|}
\hline & $\begin{array}{l}\text { YKSIKKÖ: } \\
\text { SYNKRE- } \\
\text { TISMI }\end{array}$ & $\begin{array}{l}\text { YKSIKKÖ: } \\
\text { EI SYNK- } \\
\text { RETISMIÄ }\end{array}$ & $\begin{array}{l}\text { MONIKKO: } \\
\text { SYNKRE- } \\
\text { TISMI A }\end{array}$ & $\begin{array}{l}\text { MONIKKO: } \\
\text { SYNKRE- } \\
\text { TISMI B }\end{array}$ & $\begin{array}{l}\text { MONIKKO: } \\
\text { EI SYNKRE- } \\
\text { TISMIÄ }\end{array}$ \\
\hline NOM & \multirow{2}{*}{$\begin{array}{c}15 \\
(31,9 \%)\end{array}$} & 32 & 0 & 0 & 47 \\
\hline GEN & & (32) & \multirow{2}{*}{$\begin{array}{c}7 \\
(14,9 \%)\end{array}$} & \multirow{3}{*}{$\begin{array}{c}17 \\
(36,2 \%)\end{array}$} & 23 \\
\hline PART & \multirow{2}{*}{$\begin{array}{c}10 \\
(21,2 \%)\end{array}$} & 37 & & & (23) \\
\hline ILL & & (37) & & & (30) \\
\hline
\end{tabular}

Taulukko 3. Synkretistiset tapaukset Sulev Ivan (2007: 75-58, 147-201) mukaan võrun kirjakielen sijataivutuksessa ja 47 taivutustyyppiin jakautuvassa nominiparadigmassa. 
Ivan luokittelun mukaan noin kolmasosassa võrun kirjakielen nominityyppejä vallitsee yksikön nominatiivin (NOM) ja genetiivin (GEN) välinen synkretismi. Runsaaseen kolmasosaan taivutustyyppejä vaikuttaa monikon genetiivin (GEN), partitiivin (PART) ja illatiivin (ILL) välinen synkretismi, ja yhdessä monikon genetiivin ja partitiivin välisen binaarisen synkretismin kanssa noin puolet monikon genetiivi- ja partitiivi-tyypeistä on synkretistisiä. Yksikössä sen sijaan genetiivi ja partitiivi pysyvät kauttaaltaan erillään, ja toinen yksikkömuotojen synkretismi koskee partitiivin ja illatiivin välistä binaarista synkretismiä.

Viron kirjakielessä synkretismi toimii pääpiirteissään samanlaisten ehtojen säätelemänä ja on kauttaaltaan asymmetrinen (Grünthal 2001). Ne sijat, joita ilmiö eniten koskettaa, ovat samat kolme kieliopillista sijaa eli nominatiivi, genetiivi ja partitiivi ja niiden lisäksi illatiivi. Vaikka olen edellä maininnut, että kunkin kielen ominaisimmat piirteet ilmenevät morfologiassa, on synkretismi argumentti sen puolesta, että läheisten sukukielten välillä kehitys vie usein samaan suuntaan. Konvergenssi on luontevin selitys sille, miksi synkretismi koskettaa viron ja võrun (eteläviron) lisäksi myös suomen lounaismurteissa, vatjassa ja liivissä samoja kategorioita eli erityisesti kieliopillisia sijoja ja illatiivia.

Taulukossa 4 on esitetty esimerkkejä kolmesta eri liivin nominityypistä yksikössä ja monikossa. Kaikissa kolmessa tapauksessa monikkomuotojen synkretismi rajoittuu nominatiivin ja genetiivin sulautumiseen yhteen, mikä tekee ilmiöstä symmetrisen monikossa. Yksikössä taas synkretismin muotoon vaikuttaa kulloinkin kyseessä oleva taivutustyyppi.

Liivin tapauksessa synkretismin avulla voidaan arvioida myös sitä, onko sen toteutumiselle erityisiä ehtoja. Tällaiset säännöt auttavat rajaamaan lähemmin taivutusmorfologian rakennetta. Viitso (2008: 348-355) jakaa liivin nominit yhteensä 127 tyyppiin, joista seitsemän on pronomineja, loput valtaosin substantiiveja. Synkretististen tapausten jakautuminen näiden taivutustyyppien välillä on esitetty taulukossa 5 . 


\begin{tabular}{|c|c|c|c|c|c|c|}
\hline & $\begin{array}{l}\text { 'silmä' } \\
\text { (SG) }\end{array}$ & $\begin{array}{l}\text { 'silmä' } \\
\text { (PL) }\end{array}$ & $\begin{array}{l}\text { 'vesi' } \\
\text { (SG) } \\
\end{array}$ & \begin{tabular}{|l} 
'vesi' \\
(PL) \\
\end{tabular} & $\begin{array}{l}\text { 'villai- } \\
\text { nen' (SG) }\end{array}$ & \begin{tabular}{|l|} 
'villai- \\
nen' (PL) \\
\end{tabular} \\
\hline NOM & sīlma & sīlma-d & $v e ’ \check{z}$ & vied $\bar{u}-d$ & villi & villiz- $t$ \\
\hline GEN & sīlma & sìlma-d & vie'd & vied $\bar{u}-d$ & villiz & villiz- $t$ \\
\hline PART & silmõ & silgm-i & vietā & $v e^{\prime} z ̌ z ̌ i$ & villiz- $t$ & villiž- $i$ \\
\hline DAT & sìlma-n & $\begin{array}{l}\text { sīlma- } \\
\text { dõn }\end{array}$ & vie'dd-õn & $\begin{array}{l}\text { viedu- } \\
\text { dõn }\end{array}$ & villiz-õn & villiz-tõn \\
\hline ILL & silmõ & siļm-ži & vie'ddõ & $v e \check{z} \bar{l}-z$ & villiz-õ & villiž-iz. \\
\hline
\end{tabular}

Taulukko 4. Synkretismi liivin sijataivutuksessa (Viitso 2008: 348-355).

\begin{tabular}{|c|c|c|c|c|}
\hline & $\begin{array}{l}\text { YKSIKKÖ: } \\
\text { SYNKRE- } \\
\text { TISMI }\end{array}$ & $\begin{array}{l}\text { YKSIKKÖ: } \\
\text { EI SYNKRE- } \\
\text { TISMIÄ }\end{array}$ & $\begin{array}{l}\text { MONIKKO: } \\
\text { SYNKRE- } \\
\text { TISMI A }\end{array}$ & $\begin{array}{l}\text { MONIKKO: } \\
\text { EI SYNKRE- } \\
\text { TISMIÄ }\end{array}$ \\
\hline NOM & \multirow{2}{*}{$\begin{array}{c}77 \\
(60,1 \%)\end{array}$} & 50 & \multirow{2}{*}{$\begin{array}{c}127 \\
(100 \%)\end{array}$} & 0 \\
\hline GEN & & (50) & & (0) \\
\hline $\begin{array}{l}\text { PAR } \\
\mathrm{T} \\
\end{array}$ & \multirow{2}{*}{$\begin{array}{c}44 \\
(34,6 \%)\end{array}$} & 83 & 0 & 127 \\
\hline ILL & & (83) & (0) & (127) \\
\hline
\end{tabular}

Taulukko 5. Synkretistiset tapaukset Tiit-Rein Viitson (2008: 348-355) mukaan liivin sijataivutuksessa ja 127 taivutustyyppiin jakautuvassa nominiparadigmassa.

Vertailu taulukossa 3 esitettyyn võrun kirjakielen synkretismiin osoittaa, että yksikössä erityisesti nominatiivin ja genetiivin, mutta myös partitiivin ja illatiivin välinen synkretismi on nominien taivutustyyppejä ajatellen liivissä vielä tavallisempi kuin võrun kirjakielessä. Viitson mukaan yhteensä 127 taivutustyypistä 77:ssä myös yksikön nominatiivi ja genetiivi ovat identtisiä sen lisäksi, että monikossa nämä kategoriat ovat täysin sulautuneet yhteen. Liivin sijasynkretismiin liittyy myös impli- 
katiivinen sääntö: jos yksikön partitiivi ja illatiivi ovat identtisiä, myös yksikön nominatiivin ja genetiivin on oltava identtisiä. Tällainen hierarkia lienee kuitenkin sattumaa eikä tulkittavissa sijasynkretismiä laajemmin koskevaksi säännöksi, koska se ei esimerkiksi võrun kirjakielessä päde. Jälkimmäisessä on mahdollista, että yksikön partitiivi ja illatiivi ovat identtisiä, mutta samassa taivutustyypissä nominatiivi ja genetiivi ovatkin erilaisia.

On myös huomattava, että taulukoissa 3 ja 5 esitetyt suhteelliset osuudet koskevat vain Ivan ja Viitson esittämiä taivutustyyppejä, eivät synkretististen tapausten esiintymää puheessa tai teksteissä. Silti taulukkojen tiedot valottavat osaltaan sitä, kuinka yleinen ja kielioppiin ja nominitaivutukseen erottamatta kuuluva ilmiö synkretismi on sekä võrussa että liivissä.

Liivin synkretismitapaukset paljastavat lisäksi nominityyppeihin liittyviä ehtoja, jotka valottavat osaltaan morfologisia sääntöjä. Tietyissä taivutustyypeissä muuten laajalti levinnyt yksikön nominatiivin ja genetiivin välinen synkretismi ei toteudu. Tällaisia taivutustyyppejä ovat seuraavat yksikön nominatiivin mukaan määräytyvät ryhmät:

(i) $-\check{s},-z$, ja $-\check{z}$-loppuiset nominit

(ii) $i$-loppuiset adjektiivit ja muut nominit

(iii) liudentuneeseen dentaaliin loppuvat nominit

(iv) pronominit (poikkeuksena mis 'mikä')

(v) yksittäistapaus (Viitson taivutustyyppi 98: sēr sääri: NOM: sä̈r sääri.GEN)

Kaikissa muissa liivin nominityypeissä nominatiivi ja genetiivi ovat myös yksikössä sulautuneet yhteen.

\section{Synkretismin suhde taivutusmorfologiaan}

Morfologisten paradigmojen johdonmukaisuus ja poikkeamat heijastavat erilaisten taivutusmekanismien asemaa kielessä. Loogisessa järjestelmässä ja kategorioiden rajojen hämärtymisessä piilee yksi mahdollinen selitys sille, miksi kielessä on tapahtunut muita, enemmän tai vähemmän rinnakkaisia muutoksia. Esimer- 
kiksi viron kielessä latinan habeo-verbin kaltainen finiittinen omistusrakenne on ollut marginaalinen, mutta se on alkanut viime vuosina yleistyä (Erelt ja Metslang 2006). Analogisesti leviävät partitiivin päätteet $-t$ (yks.) ja -sid (mon.) valtaavat alaa (Ehala 1997, Erelt ja Metslang 1998). Perfektiivisyyttä ilmaiseva verbipartikkeli ära on yleistynyt (Metslang 1997 ja 2001). Nämä muutokset liittyvät suoraan tai välillisesti synkretismiin, genetiivin - $n$ :n katoamiseen ja kieliopillisten sijojen muuttumiseen.

Näyttää ilmeiseltä, että muutos muodon ja merkityksen välisessä tasapainossa ja synkretismin synty ovat vuorovaikutussuhteessa myös muiden muutosten kanssa (Carstairs 1987: 128129, Erelt ja Metslang 1998: 659, Grünthal 2007, Karinš 1994). Eteläisten itämerensuomalaisten kielten osalta synkretismin esiintyminen kertoo myös osaltaan flektiivisen ja agglutinatiivisen morfologian eroista. Fleksion merkityksestä itämerensuomalaisten kielten sijataivutuksesta on aiemmin käyty keskustelua, mutta se ei kokonaisuutena toimi yhtä kattavasti ja kokonaisia morfologisia kategorioita erottavana kuin agglutinatiivinen morfologia (Blevins 2005, Grünthal 2000, Rätsep 1981, Tauli 1984, Viitso 1990).

Synkretismin lähempi tarkastelu osoittaa havainnollisesti flekteeraavan ja agglutinatiivisen morfologian välisen eron. Edellinen luo epäsymmetrisiä paradigmoja, tukeutuu taivutustyypin ohjailemiin, leksikaalisiin sääntöihin. Jälkimmäinen on kategoriakohtaisesti ennustettava, joskin siihenkin voi sisältyä pienessä määrin allomorfiaa. Jos taivutuspäätteitä johdonmukaisesti hyödyntävässä paradigmassa esiintyy kategorioiden välistä synkretismiä, kuten tässä artikkelissa tarkasteltu suomen kielen possessiivitaivutus tai liivin kielessä monikon nominatiivi ja genetiivi, se on tavallisesti symmetristä ja poikkeuksetonta.

Taulukossa 6 on esitetty kokoavasti itämerensuomalaisten kielten synkretismin ja taivutustypologian välinen korrelaatio. 


\begin{tabular}{|l|l|l|}
\hline $\begin{array}{l}\text { synkretismin ylei- } \\
\text { syys }\end{array}$ & $\begin{array}{l}\text { runsaasti } \\
\text { synkretismiä }\end{array}$ & vähän synkretismiä \\
\hline $\begin{array}{l}\text { synkretististen pa- } \\
\text { radigmojen muoto }\end{array}$ & epäsymmetrinen & $\begin{array}{l}\text { symmetrinen, käy- } \\
\text { tännössä poly- } \\
\text { semiaa }\end{array}$ \\
\hline $\begin{array}{l}\text { morfologisten } \\
\text { sääntöjen yleis- } \\
\text { tettävyys }\end{array}$ & $\begin{array}{l}\text { leksikaalisen taivu- } \\
\text { tustyypin ohjaama } \\
\text { sijataivutus }\end{array}$ & $\begin{array}{l}\text { kategoriakohtai- } \\
\text { sesti määräytyvä } \\
\text { taivutus }\end{array}$ \\
\hline $\begin{array}{l}\text { morfologinen tai- } \\
\text { vutustypologia }\end{array}$ & $\begin{array}{l}\text { flekteeraava morfo- } \\
\text { logia }\end{array}$ & $\begin{array}{l}\text { agglutinatiivinen } \\
\text { morfologia }\end{array}$ \\
\hline
\end{tabular}

Taulukko 6. Sijasynkretismin ja morfologisen typologian välinen korrelaatio itämerensuomalaisissa kielissä.

Areaalisesti sijasynkretismi on erityisesti eteläisille itämerensuomalaisille luonteenomainen piirre, joka erottamatta liittyy niiden kuvaukseen ja funktionaalisten rakenteiden dynamiikkaan. Maantieteellisellä alueella ei kuitenkaan kokonaisuuden kannalta ole niin suurta merkitystä kuin sillä, mitä kategorioita synkretismi ensisijaisesti koskettaa. Kyse ei ole koko sijataivutusta tai eteläisten itämerensuomalaisten kielten taivutusmorfologiaa kauttaaltaan hallitsevasta asiasta, vaan synkretismi liittyy ensisijaisesti nimenomaan kieliopillisiin sijoihin. Koska ne ovat suurifrekvenssisiä ja tärkeimpien nominaalisten lauseenjäsenten sijoja, niihin liittyvä synkretismi sijoittuu enemmän tai vähemmän kielen keskiöön ja lauseen ytimeen.

\author{
Riho Grünthal \\ PL 24 (Unioninkatu 40) \\ Suomalais-ugrilaiset kielet ja kulttuurit \\ FI-00014 Helsingin yliopisto \\ rgruntha@mappi.helsinki.fi
}




\section{Lähteet}

Aronoff, Mark, Kirsten Fudemann (2005) What is morphology. Oxford: Blackwell Publishing.

Baerman, Matthew, Dunstan Brown (2005) "Case syncretism”. Martin Haspelmath, Matthew S. Dryer, David Gil, Bernard Comrie, toim. The world atlas of language structures. Oxford: Oxford University Press.

Baerman ym. 2005 = Baerman, Matthew, Dunstan Brown, Greville C. Corbett (2005) The syntax-morphology interface. A study of syncretism. Cambridge: Cambridge University Press.

Baerman, Matthew, Greville C. Corbett (2007) "Linguistic typology: Morphology”. Linguistic Typology 11, 115-117.

Bátori, István (1990) "Die Markierung des Objekts am Verb im Mordwinischen, morphologische Umbestimmtheit und Homomorphie". Nyelvtudományi Közlemények 91, 15-23.

Bauer, Laurie (1988) Introducing linguistic morphology. Edinburgh: Edinburgh University Press.

Bickel, Balthasar, Johanna Nichols (2007) "Inflectional morphology". Timothy Shopen, toim. Language typology and syntactic description 3. Grammatical categories and the lexicon, 169-240. Cambridge: Cambridge University Press.

Blevins, Jim (2005) "Word-based declension in Estonian”. G. Booij, J. van Marle, toim.. Yearbook of Morphology 2005, 1-25. Amsterdam: Springer.

Carstairs, Andrew (1987) Allomorphy in inflexion. London: Croom Helm.

Croft, William (2000) "Lexical and grammatical meaning". Geert Booij, Christian Lehmann, Joachim Mugdan, toim. Morphology. An International handbook on inflection and word-formation, 257263. Berlin: Walter de Gruyter.

Ehala, Martin (1997) „Eesti morfoloogia olemus“. Keel ja Kirjandus 40, 6, 370-383.

Erelt ym. 1993-1995 = Erelt, Mati, Reet Kasik, Helle Metslang, Henno Rajandi, Kristiina Ross Henn Saari, Kaja Tael, Silvi Vare Eesti keele grammatika I-II. Trükki toimetanud Mati Erelt (peatoimetajana), Tiiu Erelt, Henn Saari, Ülle Viks. Tallinn: Eesti Teaduste Akadeemia Eesti Keele Instituut, II-1993 I-1995.

Erelt ym. 1997 = Erelt, Mati, Tiiu Erelt, Kristiina Ross (1997) Eesti keele käsiraamat. Tallinn: Eesti Keele Sihtasutus.

Erelt, Mati, Helle Metslang (1998) „Oma või võõras?“. Keel ja Kirjandus 41, 10, 657-668. 
Erelt, Mati, Helle Metslang (2006) "Estonian clause patterns - from Finno-Ugric to standard average European". Linguistica Uralica XLII, 17, 254-266.

Grünthal, Riho (2000) "Typological characteristics of the Finnic languages: a reappraisal”. Johanna Laakso, toim. Facing Finnic, 3163. (Castrenianumin toimitteita 59.) Helsinki.

Grünthal, Riho (2001) "Homonymy and systemacy in Estonian inflection”. Reet Kasik, toim. Keele kannul. Pühendusteos Mati Erelti 60. sünnipäevaks 12. märtsil 2001, 42-61. (Tartu ülikooli eesti keele õppetooli toimetised 17.) Tartu.

Grünthal, Riho (2002) „Vormihomonüümia ja muutuv keel“. Reet Kasik, toim. Lähivertailuja 12. Soome-eesti kontrastiivseminar 30.5.1.6.2001 Kääriku, 21-34. (Tartu ülikooli eesti keele õppetooli toimetised 19.) Tartu: Tartu Ülikool.

Grünthal, Riho (2003) Finnic adpositions and cases in change. (Suomalais-Ugrilaisen Seuran Toimituksia 244.) Helsinki: SuomalaisUgrilainen Seura.

Grünthal, Riho (2007) "Morphological change and the influence of language contacts in Estonian". Hans Fix, toim. Beiträge zur Morphologie. Germanisch, baltisch, ostseefinnisch, 402-432. Odense: University Press of Southern Denmark.

Haspelmath, Martin (2007) "Pre-established categories don't exist: Consequences for language description and typology". Linguistic Typology 11, 119-132.

Hopper, Paul, Elizabeth Traugott (1993) Grammaticalization. Cambridge: Cambridge University Press.

ISK = Hakulinen, Auli (päätoimittaja), Maria Vilkuna, Riitta Korhonen, Vesa Koivisto, Tarja R. Heinonen, Irja Alho (2004) Iso suomen kielioppi. Helsinki: Suomalaisen Kirjallisuuden Seura.

Iva, Sulev (2007) Võru kirjakeele sõnamuutmissüsteem. (Dissertationes philologiae estonicae universitatis tartuensis 20.) Tartu: Tartu Ülikooli Kirjastus.

Joseph, Brian D. (1990) Morphology and universals in syntactic change : evidence from medieval and modern Greek. New York: Garland Publishing.

Johnston, Jason (1997) Systematic homonymy and the structure of morphological categories. Some lessons from paradigm. Department of Linguistics University of Sydney. <http:// ses.library.usyd. edu.au/bitstream/2123/396/1/adt-NU1999.0013whole.pdf>. Luettu 11.4.2010.

Kangasmaa-Minn, Eeva (1992) "Pienimuotoinen kieliperimämme". Sananjalka 34, 21-31. 
Karinš, A. Krišjanis (1994) "Functionalism and linguistic change in Latvian verb morphology”. Linguistica Baltica 3, 109-120.

Keem, Hella (1997) Võru keel. Tallinn: Emakeele Selts, Võru Instituut.

Keresztes, László (1999) Development of Mordvin definite conjugation. (Suomalais-Ugrilaisen Seuran Toimituksia 233.) Helsinki: Suomalais-Ugrilainen Seura.

Kettunen, Lauri (1938) Livisches Wörterbuch mit grammatischer Einleitung. (Lexica Societas Finno-Ugricae V.) Helsinki: SuomalaisUgrilainen Seura.

Kettunen, Lauri (1960) Suomen lähisukukielten luonteenomaiset piirteet. (Suomalais-Ugrilaisen Seuran Toimituksia 119.) Helsinki: Suomalais-Ugrilainen Seura.

Laanest, Arvo (1982) Einführung in die ostseefinnischen Sprachen. Hamburg: Helmut Buske Verlag.

Leino, Pentti (1993) Polysemia - kielen moniselitteisyys. (Kieli 7.) Helsinki: Helsingin yliopiston suomen kielen laitos.

Leino, Pentti, Tiina Onikki, toim. (1994) Suomen kielen kognitiivista kielioppia 2. Näkökulmia polysemiaan. (Kieli 8.) Helsinki: Helsingin yliopiston suomen kielen laitos.

Luraghi, Silvia (2008) "Synkretismus". Geerd Booij, Christian Lehmann, Joachim Mugdan, toim. Morphologie: Ein Handbuch zur Flexion und Wortbildung, 638-647. Berlin: Mouton de Gruyter.

Malchukov, Andrej, Andrew Spencer, toim. (2009) The Oxford handbook of case. Oxford: Oxford University Press.

Meiser, Gerhard (1992) "Syncretism in Indo-European languages motives, processes, results". Transactions of the Philological Society $90,187-218$.

Metslang, Helle (1997) „Eesti prefiksaaladverbist ära soome keele taustal“". Riho Grünthal, Reet Kasik, toim. Lähivertailuja 9. Suomalais-virolainen kontrastiiviseminaari 3.-5.5.1996 Lammi, 31-46. (Castrenianumin toimitteita 53.) Helsinki: Suomalais-Ugrilainen Seura. Metslang, Helle (2001) "On the developments of the Estonian aspect: The verbal particle ära”. Östen Dahl, Maria Koptjevskaja-Tamm, toim. Circum-Baltic languages 2: Grammar and typology, 443479. Amsterdam: John Benjamins.

Miestamo, Matti (2006) "On the complexity of standard negation". Mickael Suominen, Antti Arppe, Anu Airola, Orvokki Heinämäki, Matti Miestamo, Urho Määttä, Jussi Niemi, Kari K. Pitkänen, Kaius Sinnemäki, toim. A man of measure: Festschrift in Honour of Fred Karlsson on His 60th Birthday, 345-356. Special Supplement to SKY Journal of Linguistics 19.) Turku: Suomen Kielitieteellinen Yhdistys. 
Paunonen, Heikki (2003) "Suomen kielen morfologisista muutosmekanismeista". Lea Laitinen, Hanna Lappalainen, Päivi Markkola, Johanna Vaattovaara, toim. Muotojen mieli. Kirjoituksia morfologiasta ja variaatiosta, 187-248. (Kieli 15.) Helsinki: Helsingin yliopiston suomen kielen laitos.

Paunonen, Heikki (2006) "Synonymia Helsingin slangissa". Virittäjä $110,3,336-364$.

Rätsep, Huno (1981) "Some tendencies in the development of Estonian”. Sovetskoe Finno-Ugrovedenie 17, 202-211.

Stump, Gregory (2001) Inflectional morphology. A theory of paradigm structure. Cambridge: Cambridge University Press.

$\mathrm{SD}=$ The Surray Sycretisms Database <http://www.smg.surrey.ac.uk/ Syncretism/> Luettu 3.5.2010.

Tauli, Valter (1984) "Is the structural change of languages really predestined?" Ural-Altaische Jahrbücher Neue Folge 4, 25-35.

Tikka, Toivo (1992) Vepsän suffiksoituneet postpositiot. Kieliopillisiin sijoihin liittyvä suffiksoituminen. (Studia Uralica Upsaliensia 22). Uppsala: Uppsala Universitet.

Viitso, Tiit-Rein (1990) „Eesti keele kujunemine flekteerivaks keeleks". Keel ja Kirjandus 33, 8-9, 456-461, 542-548.

Viitso, Tiit-Rein (2008) Liivi keel ja läänemeresoome keelemaastikud. Tartu-Tallinn: Eesti Keele Sihtasutus.

Viks, Ülle (1984) „Sõnavormide homonüümia eesti keeles“. Keel ja Kirjandus 27, 2, 97-105.

Riho Grünthal. The Role of Syncretism in the Morphology of the Finnic Languages. Syncretism and the overlapping of morphologically distinct units or entire categories have different influences on morphosyntactically cumulative and less cumulative forms. The Finnic languages, in comparison to the more eastern Finno-Ugric languages, mainly display morphologically less complex forms. In this respect, the occurrence of syncretism strongly violates the ideal balance between one form and function.

Morphologically there is a clear distinction in the way syncretism is manifested in the Finnic languages that, consequently, is one of the most distinct features in the inflectional system despite the close genealogical affinity. This can concretely be seen in the differences in the case inflection of the southern, such as Livonian, Estonian and Votic, and northern Finnic languages, most notably Finnish, Karelian and Veps. The comparison of syncretism in these languages shows both cross-linguistic regularity and language-specific rules that determine 
syncretic forms. Diachronic change and the erosion of suffixal elements are closely involved in the rise of syncretism. The paper examines the symmetries and asymmetries in the occurrence of syncretic forms in Finnic case paradigms.

Keywords: morphology, syncretism, typology, Finnic languages, South Estonian, Livonian 